\title{
AUSTRALIAN CARABID BEETLES XI. SOME TACHYS ${ }^{1}$
}

\author{
By P. J. Darlington, JR. \\ Museum of Comparative Zoology, Cambridge, Mass.
}

The preceding part of this series (Darlington 1962) dealt with the Australian species of Bembidion. The present part deals with some smaller Bembidiini of the genus Tachys. Australian Tachys have been treated twice by Sloane (I896; I92I), whose papers should be consulted for references and synonymy. I shall now consider only selected groups of the genus about which I have something new to say.

Australian species of Tachys are much more numerous and less well known than those of Bembidion. They are phylogenetically diverse as well as numerous and include several peculiar groups which may be relict, or specialized. For example Tachys amplipennis Macleay has the elytron fully striate with grooved striae and seems to lack the apical striole that characterizes most Tachys. However the apex of the 7 th stria is deeply impressed, with a puncture beside it on the inner side, and this part of the 7 th stria is almost separated from the main part of the stria in some individuals. This condition may be primitive and may show how the apical striole originated. However, some other Tachys have the apical striole attached to the 3rd stria (see Tachys ectromioides group in the following pages, and also Tachys yarrensis Blackburn, which will be treated in the next paper of this series).

Species of Tachys are numerous, diverse, and frequently collected almost everywhere on the continent of Australia, including Victoria, but are comparatively few in Tasmania. Sloane ( I920, I5 I) records only four, well known Australian species from the island. In four months' collecting on Tasmania I encountered Tachys on only three occasions: once in stone and gravel banks and bars of the King River at the crossing of the Queenstown road, where I found T. ("Bembidion") hobarti Blackburn and a related new species; once on the bank of the Mersey River, where I took one hobarti by washing gravel; and once beside the Arve River in southern Tasmania, where I found one specimen of $T$. australis Schaum under a stone.

The distribution of Tachys in Tasmania and southern Australia

\footnotetext{
${ }^{1}$ Published with a grant from the Museum of Comparative Zoology at Harvard College.

Manuscript received by the editor March 19, 1962.
} 
is complementary to that of the Trechini. The latter are numerous in Tasmania and decrease rapidly northward on the mainland, where Tachys increases in numbers. The two groups tend to be complementary ecologically too. Most Tachys live beside standing or running water or in swamps, often in open as well as forested country. Most Australian (including Tasmanian) Trechini live on the ground in wet forest but not beside open water. [What I have just said about complementarity of Tachys and Trechini is true and important, but an oversimplification. The two groups overlap both geographically and ecologically in ways that are too complex to describe here.]

\section{Tachys hobarti group}

In I92 I (p. 193) Sloane mentioned as unknown to him two supposed Bembidion described by Blackburn: hobarti of Tasmania and wattsense of Victoria. I can now say that hobarti is a Tachys, not a Bembidion. The oblique truncation of the outer angle of the anterior tibia is (as Blackburn said) less marked in hobarti than usual in Tachys, but absence of a scutellar stria and presence of a (modified) apical striole mark the species as Tachys. I think that the Victorian wattsense may be a synonym of hobarti. The former is described as having 5 and the latter 6 dorsal striae on each elytron, but both conditions occur in my series of hobarti from the King River. Sloane's leai may be the same thing, although I do not want to declare the synonymy without comparing specimens. Sloane's murrumbidgensis is a related species. And 3 additional species that seem to be new, one of them remarkable for reduction of elytral striation, are described below. All these species, and perhaps additional ones still to be discovered, form what may be called the hobarti group of Tachys. Although they are certainly Tachys rather than Bembidion by current classification, the species of this group are anomalous (primitive ?) in some ways and should be specially considered by students of bembidiine phylogeny.

Characteristics of the hobarti group are: form subparallel (but elytra considerably wider than prothorax), moderately convex; upper surface usually punctulate (scarcely so in lutus). Head large (short but wide, with neck very wide and not impressed); eyes of moderate size but rather prominent; antennae rather short, with median segments $2 \times$ or less long as wide, and segment 3 usually slightly longer than 2; clypeus truncate or broadly emarginate, impressed at middle anteriorly in some species; mentum not perforated at base, with a simple tooth at middle. Prothorax subcordate, more or less lobed across base, 
so that posterior angles are sometimes not quite basal (but I have measured width of base of prothorax across the prominent sub-basal angles) ; apex subtruncate; lateral margins narrow, each with usual 2 setae; disc with anterior transverse impression obsolete, middle line moderately or lightly impressed but extending posteriorly behind transverse sulcus, and latter variably impressed, sometimes interrupted at middle. Elytra with rather prominent but more or less rounded humeri; margins not serrate or faintly so; sutural stria entire and deeply impressed; 5th stria deeply impressed at base (except in lutus); 8th stria absent excepting an apparent remnant deeply impressed near apex and including 2 strong punctures; apical striole ending anteriorly in or (usually) reduced to a conspicuous elongate puncture; 3 rd interval or stria 3-punctate. Inner wings fully developed. Abdomen sparsely, inconspicuously pubescent; front tibia with outer apical angle less strongly oblique than usual in Tachys; posterior tarsi rather short; males with 2 segments each front tarsus widely dilated, and males with I, females 2 setae each side apex last ventral segment.

The known range of the hobarti group is Tasmania and temperate southeastern Australia north to Rockhampton. All the species occur in sand or gravel or under stones by rivers or brooks. Some of the species superficially resemble Perileptus, with which they sometimes occur.

Key to species of Tachys of hobarti group

I. Dorsal striae (except sutural) obliterated lutus

- Stria 5 and usually some other dorsal striae distinct at least in part

2. Striae I and 5 well impressed but 2-4 light, irregular, sometimes hardly traceable; clypeus not impressed anteriorly; rather shining; size small (length $c$. I. $8 \mathrm{~mm}$.) kingi

- Striae 2-4 distinct and individually traceable at least behind anterior dorsal puncture, although less impressed than $\mathrm{I}$ and 5; other characters variable, but none of the following species has all the characters given above for kingi

3. Black; more shining, with microsculpture less distinct; clypeus not distinctly impressed; length $2.3-2.7 \mathrm{~mm}$. (may include wattsense Blackburn and leai Sloane) hobarti Reddish; less shining, with microsculpture (microreticulation and punctulation) more distinct; clypeus impressed at middle anteriorly 
4. Length $c .1 \cdot 75-2.4 \mathrm{~mm}$. murrumbidgensis

- Length $c .2 .5-2.8 \mathrm{~mm}$. fitzroyi

Tachys lutus n. sp.

Figure I

With characters of hobarti group as given above, but dorsal striae (except sutural) obliterated; form (Fig. I) rather slender but convex; dark reddish piceous, appendages reddish testaceous; shining, virtually without dorsal microsculpture or punctulation. Head .89 width pro-
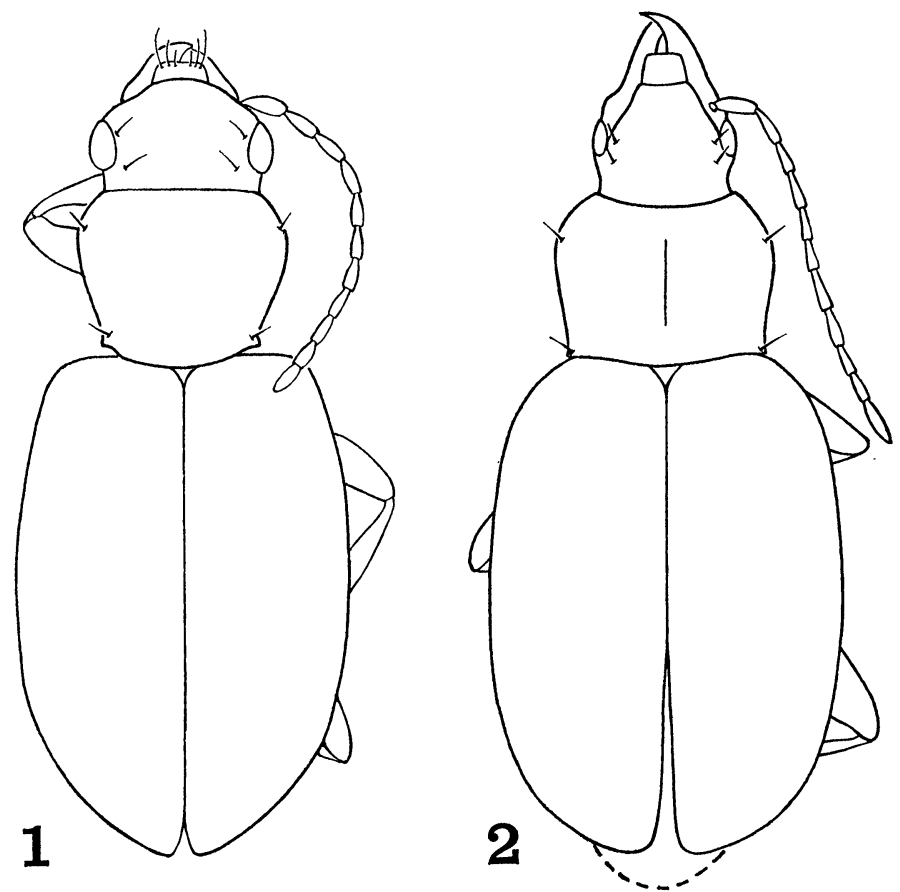

Fig. 1. Tachys lutus new species. Fig. 2. Tachys bolus new species.

thorax; eyes moderate in size and prominence; antennae with median segments (not counting pubescence) hardly $2 \times$ long as wide; clypeus subtruncate (slightly emarginate), not impressed anteriorly; frontal sulci irregularly subparallel, extending onto clypeus; front slightly convex, impunctate except faintly punctulate at $54 \times$ in good light; mentum with an entire tooth. Prothorax subcordate; width/length I.2I; base/apex $c .1 .04$; base/head .85 ; sides arcuate anteriorly, 
oblique and strongly converging posteriorly, strongly but briefly sinuate before posterior angles; latter forming small, sub-basal, rectangular projections; apex truncate; base subtruncate; disc with anterior transverse impression and middle line almost obsolete but latter coarse basally; sulcus coarsely foveate. Elytra more than $1 / 2$ wider than prothorax (E/P I.57), probably widest about middle (slightly spread), not margined basally (margin ending a little inside humeri); margins not visibly serrate or setulose (at $54 \times$ ); sutural stria entire, punctate anteriorly, groove-like posteriorly; other dorsal striae obliterated, including 5 th, which is at most faintly indicated toward base; apical striole reduced to a coarse slightly elongate puncture on declivity, nearer margin than suture; 3 dorsal punctures on each elytron before anterior $1 / 4$, near middle, and behind $3 / 4$. Length c. 2.5 ; width $c . .95 \mathrm{~mm}$.

Holotype (M. C. Z. Type No. 30327) o from Termeil (north of Bateman's Bay and east of the upper Clyde River), southern New South Wales, October 1957, taken by myself. It was actually found northwest of Termeil, well up in the hills, where I followed a system of wood roads nearly to (south of) a conspicuous summit called the Pigeon House. Here, in a small valley of eucalyptus woods, was a small brook, nearly dry but with water still in the pools, which were margined by sand bars. The single specimen of the present species was taken by washing sand at the water's edge.

The obliteration of the elytral striae (except the sutural) makes this a distinct and easily recognizable species.

\section{Tachys kingi n. sp.}

With characters of hobarti group as described above. Small, moderately elongate, moderately convex; dark rufous, head slightly darker, appendages not much paler; shining, reticulate microsculpture faint above but head and pronotum distinctly, sparsely punctulate. Head $.86 \& .87$ width prothorax (in $0^{7} 9$ measured); antennae with middle segments not quite $2 \times$ long as wide; clypeus truncate, not impressed anteriorly (checked in all specimens); frontal sulci irregularly subparallel, reaching and diverging on clypeus. Prothorax subcordate, width/length I.30 \& I.28; base/apex .89 \& .93; base/head .8 \& \& .79; sides rounded anteriorly, oblique and strongly converging posteriorly, rather strongly sinuate before angles; latter sub-basal, forming nearly rectangular projections; disc with anterior impression obsolete, middle line lightly impressed, basal sulcus moderate, faintly punctulate, not 
foveate unless at intersection of middle line. Elytra $\mathrm{I} / 3$ or more wider than prothorax (E/P I.34 \& I.44); margins behind humeri faintly subserrate and setulose; sutural striae entire, stria 5 well impressed in about basal half and reaching humerus, stria 2 less impressed, and striae 3 and 4 irregularly and usually rather faintly indicated; apical striole reduced to a conspicuous elongate puncture. Length $c$. I.8; width $c .0 .7 \mathrm{~mm}$.

Holotype $\sigma^{*}$ (M. C. Z. Type No. 30328) and io paratypes all from the King River just below the crossing of the road from Lake St. Clair to Queenstown. The specimens were taken with hobarti, under stones, on stone-and-gravel bars.

This species is about the size of typical T. murrumbidgensis. I do not have specimens of the latter, but kingi evidently differs in having elytral striae 2-4 less distinct, clypeus not impressed, and upper surface more shining.

\section{Tachys hobarti (Blackburn)}

Bembidium hobarti Blackburn 1901, 123.

?Bembidium wattsense Blackburn 1901, 123.

?Tachys leai Sloane 1896, 358, 370 .

A rather elongate, black or blackish species, with characters of hobarti group. Head $.87 \& .88$ width prothorax; clypeus not or not distinctly impressed anteriorily (checked in all specimens). Prothorax subcordate; width/length I.3 I \& I.34, base/apex .93 \& .91; base/head $.82 \& .8 \mathrm{I}$; posterior angles right-acute, nearer base than in preceding species but separated from basal lobe by brief, strong sinuations. Elytra much wider than prothorax (E/P I.47 \& I.46); each with 5 or 6 discal striae (stria 6 variable). Length 2.3-2.7; width o.8-I.o $\mathrm{mm}$.

This species was described from near Hobart, Tasmania. I rediscovered it at the King River and later found a specimen by the Mersey River, Tasmania, as noted in the preceding general discussion of Tachys. If the synonymy suggested above is correct, this species has been found on the mainland of Australia on the bank of the Watts River, a tributary of the Yarra, east of Melbourne, Victoria (wattsense), and at Tamworth, New South Wales (leai).

\section{Tachys murrumbidgensis Sloane}

Sloane 1895, 407.

A small, piceous species, with clypeus impressed anteriorly (noted by 
Sloane). Measurements (of types, $t$. Sloane) : length 1.75 ; width $0.75 \mathrm{~mm}$.

Described from 2 specimens from Narrandera, New South Wales, and later (I92I, 203) recorded by Sloane from "sand banks and pebble beds" by the margins of the following rivers, all in New South Wales: Murray (at Mulwala), Murrumbidgee (at Narrandera), Cudgegong (at Mudgee), and Macquarie (at Narromine).

\section{Tachys fitzroyi n. sp.}

With characters of hobarti group as described above. Larger and slightly broader than most species of group; dark rufous, appendages not much paler; not very shining, reticulate microsculpture distinct above but not deeply impressed, and whole upper surface sparsely punctulate. Head .91 \& .90 width prothorax; clypeus subtruncate or slightly emarginate, impressed at middle anteriorly so that it is subtuberculate each side at apex (in all specimens); frontal sulci subparallel, diverging posteriorly, extending across clypeus as sharply defined parallel grooves. Prothorax broadly subcordate; width/length I.33 \& I.37, base/apex $.85 \& .85$, base/head $.75 \& .78$; sides rather broadly rounded for much of length, strongly converging posteriorly, abruptly sinuate before posterior angles; latter sub-basal, forming rather small $c$. rectangular prominences; disc with middle line distinct, basal sulcus moderate, not foveate but vaguely punctulate. Elytra about 3/ro wider than prothorax (E/P I.32 \& I.29); margin behind humeri finely scalloped and setulose; sutural striae entire, stria 2 nearly entire but less impressed, stria 5 strongly impressed basally to humerus, striae 3-4 light and slightly irregular but plainly traceable except less distinct at extreme base, striae 6-7 at most faintly indicated; apparent apical striole present but irregularly impressed, ending anteriorly in a coarse impression; 3rd stria 3-punctate, anterior puncture before $1 / 4$ of elytral length and almost joining 3 rd to 4 th stria, other punctures near middle and behind $3 / 4$ of elytral length. Length 2.52.8 ; width $c$. O.9-I.I mm.

Holotype $0^{x}$ (M. C. Z. Type No. 30329) and 22 paratypes all from the Fitzroy River a few miles north of Rockhampton, Queensland, November 1957, taken by myself. They were in gravel and cobble stone river bars and occurred with Perileptus, which they resembled superficially.

This is probably the supposed large form of Tachys murrumbidgensis referred to by Sloane ( $192 \mathrm{I}, 203$ ) as occurring with the smaller 
typical form at Narromine. I have two reasons for considering it a distinct species. First, the size range given by Sloane (loc. cit.) for murrumbidgensis ( $1.75-2.75 \mathrm{~mm}$.) is greater than expected in a population of one species. And second, my series from the Fitzroy River includes only the large form, which apparently therefore exists separately.

\section{Tachys ectromioides group}

Tachys ectromioides Sloane is a very distinct, large, rare species. The reason for its rarity is probably its habitat. It, like the related species described below, probably lives in debris, loose soil, or rotten wood on the ground in heavy, damp woods, not associated with surface water. This is a habitat where (in southern Australia) one expects to find "Trechus" rather than Tachys, and in fact I mistook Tachys bolus for a trechine when I collected it. Small Carabidae in this habitat are rarely found by ordinary collecting methods. They can be taken by sifting, but this is laborious and must be done persistently in just the right place in order to get specimens. They can be taken more easily and in greater numbers by shoveling debris and loose soil into quiet water and catching the insects as they come to the surface. I have not found $T$. ectromioides itself, but I have collected series of 2 new related species by this method. The 3 species concerned may be considered to form the Tachys ectromioides group.

Important characters of the Tachys ectromioides group are: form broad with base of prothorax broad; color variable; upper surface not punctulate (but with reticulate microsculpture). Head rather long; frontal sulci not extending onto clypeus but produced posteriorly and vaguely joining depressed areas behind eyes, so latter on poorly defined ocular hemispheres; antennae varying in length, segment 3 not or slightly longer than 2 ; mentum with 2 deep impressions at base (but not perforated) and with entire median tooth. Prothorax with posterior angles costate. Elytra with humeri broadly rounded; margins ending inwardly about opposite ends 6 th striae, not serrate or setulose ; striation entire or nearly so but lightly impressed laterally and apically; 8th stria parallel to margin, deep posteriorly, lighter or irregular anteriorly; apical striole well impressed, long, approaching or joining end of 3rd stria anteriorly, with a fixed puncture on inner side well back; dorsal punctures present or absent, if present, 2 on each 3 rd interval. Inner wings long and folded, probably fit for flight in bolus, perhaps not in bolellus. Lower surface almost impunctate, not (or at 
most very inconspicuously) pubescent. Male with 2 segments each front tarsus slightly dilated, inconspicuously squamulose; $0^{\pi}$ with I, o 2 setae each side last ventral segment.

\section{Key to species of Tachys ectromioides group}

I. Elytra fasciate, brown on testaceous; dorsal elytral punctures present, though small ; length $c .3 \mathrm{~mm}$. ....................ectromioides

- Elytra unicolorous; dorsal elytral punctures absent ectromioides

2. Bicolored, head and prothorax rufous, elytra castaneous; length 3.2-3.6 mm. bolus

- Color wholly castaneous; length 2.6-2.8 mm. bolellus

\section{Tachys ectromioides Sloane}

Sloane 1896, 356, 359; 1898, 477; 1921, 195 (prothorax), 198, 204.

Sloane described this species as with ". . . elytra testaceous, a very wide dark piceous fascia across disc considerably behind base, apex widely piceous ..." and ". . . third elytral interval with two small setigerous punctures - the anterior just before, the posterior just behind discoidal piceous fascia ..." The type of the species (now in the Macleay Museum at Sydney) was said to be from Donnybrook, Western Australia, but Sloane later ( I898) suggested that this was probably an error. The species has been found at the Richmond River, northern New South Wales (Sloane I898); on the Blue Mts., New South Wales; and near Melbourne, Victoria (Sloane I92I, 204). I have not collected it but have briefly examined a specimen at the British Museum, unfortunately without looking for the dorsal elytral punctures. The possible habitat of the species is suggested in discussion of the group.

\section{Tachys bolus n. sp.}

Figure 2

With characters of Tachys ectromioides group as here defined; form as figured (Fig. 2). Head and prothorax rufous, former darker posteriorly and at sides, elytra dark reddish castaneous, appendages rufous; moderately shining but with distinct microsculpture isodiametric on front, isodiametric or slightly transverse on pronotum, present as very fine transverse lines on elytra, which are vaguely iridescent. Head .66 \& .65 width prothorax; antennae rather long, middle seg- 
ments $c .3 \times$ long as wide; palpi slender, last segments rather long (in genus) but slender, subulate. Prothorax strongly narrowed anteriorly, slightly so posteriorly; width/length I.32 \& $\mathrm{I} .33$; base/apex $c$. I. .58 \& I.47; base/head I.38 \& I.37; apex subtruncate, slightly lobed at middle; base subtruncate, broadly and slightly lobed at middle; sides broadly arcuate through much of length, broadly but rather slightly sinuate posteriorly; posterior angles $c$. right, well defined, costate; lateral margins moderate anteriorly, slightly broader posteriorly, each with usual 2 setae about $2 / 5$ from apex and near basal angle; anterior transverse impression of disc broad, not sharply defined; middle line rather coarse and well impressed, coarser basally and reaching base; basal sulcus distinct but not foveate, interrupted at middle by longitudinal impression; baso/lateral areas broadly depressed. Elytra broad (E/P I.59 \& I.6I ), somewhat rounded at sides, widest about middle; striae moderately impressed, slightly, irregularly punctulate; dorsal punctures lacking. Length 3.2-3.6; width I.3-1.6 mm.

Holotype $\sigma^{\pi}$ (M. C. Z. Type No. 30332) and I9 paratypes all from Bellangry Forest, northwest of Wauchope, New South Wales, about $3000 \mathrm{ft}$. altitude, April 1958, taken by myself. Also one specimen, not a type, from Barrington Tops, Mount Royal Range, about 4000 ft., October 1957, also taken by myself. All specimens were taken among lumps of dirt and in loose soil in damp situations. The first one at Bellangry Forest was washed from dirt and leaf litter from the ground in wet forest. After finding it, I searched for additional specimens without success until I started kicking the actual broken earth bank of a small brook into the water. Then the series here recorded was collected without much trouble. The Barrington Tops individual was taken among lumps of earth beside a seepage near the top of the road that led up from the Allyn River toward (but at that time not quite to) the plateau.

This species was very Trechus-like in life. It is somewhat Trechuslike even under the microscope, although its technical characters (subulate palpi, elytral striation, etc.) leave no doubt that it is a Tachys. It is evidently related to ectromioides, but differs as indicated in the key. The absence of dorsal elytral punctures in this and the following species is unexpected, but $I$ have examined all specimens of both the present and following species at about Ioo $\times$ under fluorescent illumination, which reduces surface reflection and makes minute details clear, and have not found any trace of dorsal punctures in any specimen. 


\section{Tachys bolellus n. sp.}

With characters of ectromioides group as here defined. Color dark reddish castaneous, appendages rufous; rather shining, reticulate microsculpture of upper surface isodiametric on front, finer and strongly transverse on disc of pronotum but isodiametric and in part actually longitudinal in anterior-median area of pronotum, scarcely resolved on elytra but probably present as very fine transverse lines, for elytra slightly iridescent. Head $.68 \& .64$ width prothorax; antennae relatively short, middle segments $c . \mathrm{I} / 2 \times$ or slightly more long as wide. Prothorax strongly narrowed anteriorly, much less so posteriorly; width/length I.29 \& I.39; base/apex I.46 \& I.43; base/head I.27 \& I.34; apex subtruncate or very broadly emarginate; base subtruncate, very slightly lobed at middle; sides rather broadly arcuate anteriorly, nearly straight and moderately converging posteriorly, slightly or scarcely sinuate before base; lateral margins moderate anteriorly, slightly broader posteriorly, each with usual 2 setae at apical 2/5 and basal angle; basal angles slightly obtuse (nearly right), sharply defined, costate; disc with rather vague anterior transverse impression, strongly impressed middle line, broader basally, and reaching base; basal sulcus well impressed, interrupted at middle; baso-lateral impressions rather large, deep, margined posteriorly, and margined exteriorly by strong costae. Elytra broad (E/P I.49 \& I.48), oval, widest near or slightly behind middle; all striae indicated, but outer ones faint or almost obsolete; dorsal punctures lacking. Length 2.6-2.8; width I.I-I.2 mm.

Holotype $\sigma^{\top}$ (M. C. Z. Type No. 30333) and 8 paratypes all from the Williams River Valley a little above Barrington House, at the foot of the Mount Royal Range, New South Wales, October I957, taken by myself. All the specimens were taken by washing wood-debris from a rotten log lying on the ground in heavy gallery forest near the river.

The present new species is sufficiently distinguished from bolus and ectromioides in the preceding key.

(Some additional Tachys will be treated in the next number of this series.)

\section{REFERENCES}

BLACKBURN, T.

1901. [Australian Bembidiini.] Trans. R. Soc. South Australia, 25: 120-124.

Darlington, P. J., JR.

1962. Australian carabid beetles X. Bembidion. Breviora (in press). 
SLOANE, T. G.

1895. Tachys murrumbidgensis. Proc. Linn. Soc. New South Wales (ser. 2), 9: 407-408.

1896. [Australian Tachys.] Proc. Linn. Soc. New South Wales, 21 : 355377, 407-409.

1898. [Carabidae from Western Australia.] Proc. Linn. Soc. New South Wales, $23:$ 444-520.

1920. Carabidae of Tasmania. Proc. Linn. Soc. New South Wales, 45: 113-178.

1921. [Australian Bembidiini.] Proc. Linn. Soc. New South Wales, 46: 192-208. 

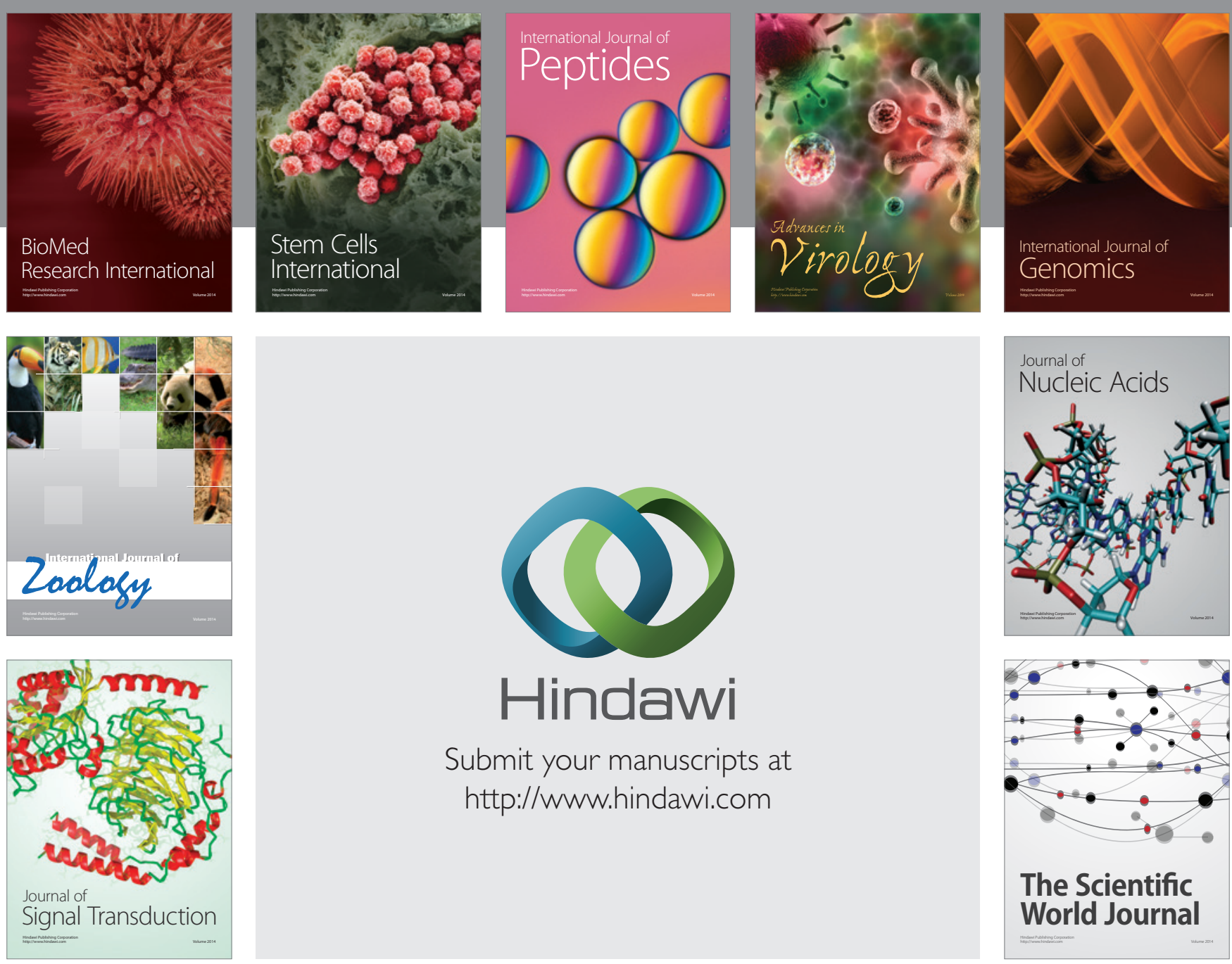

Submit your manuscripts at

http://www.hindawi.com
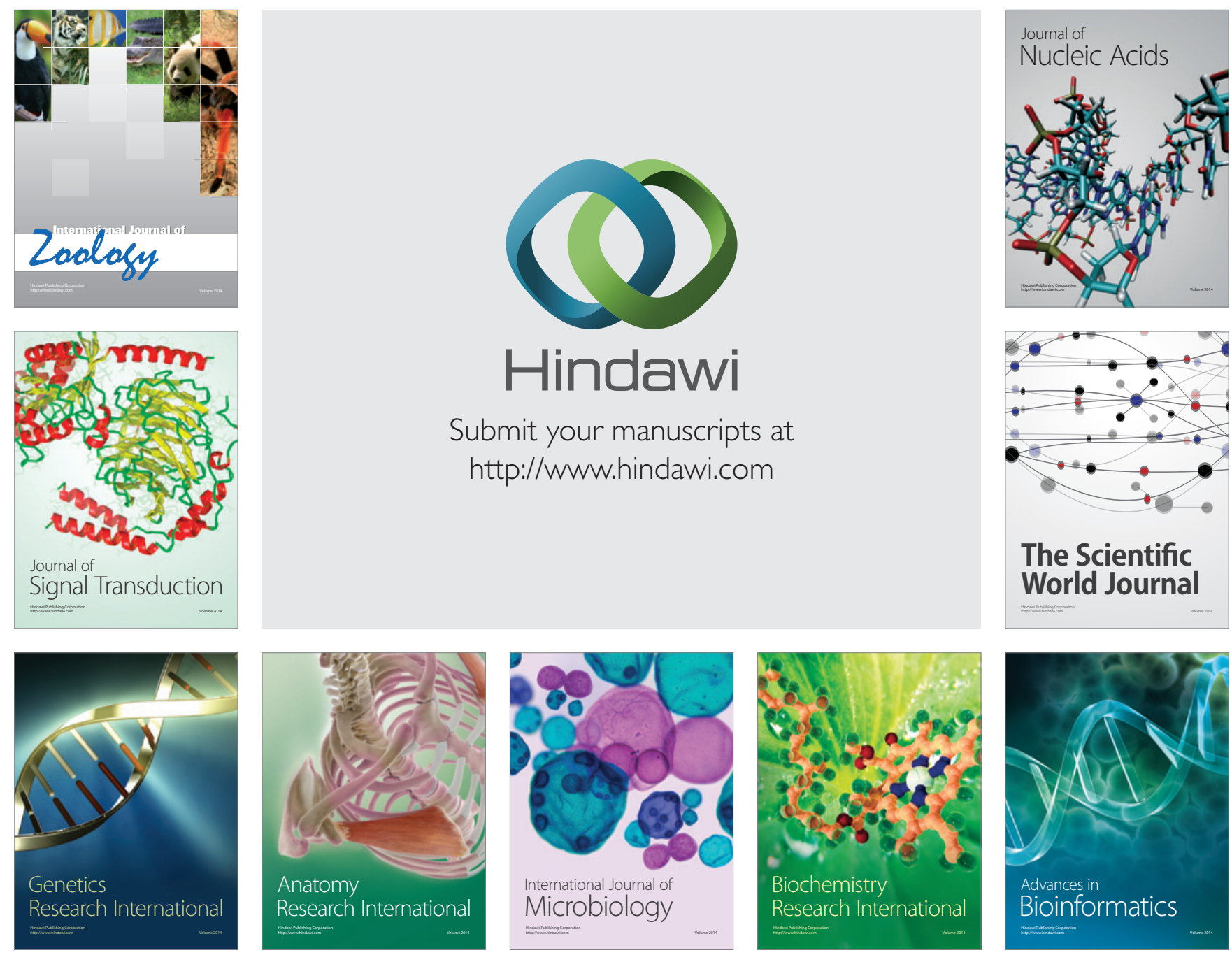

The Scientific World Journal
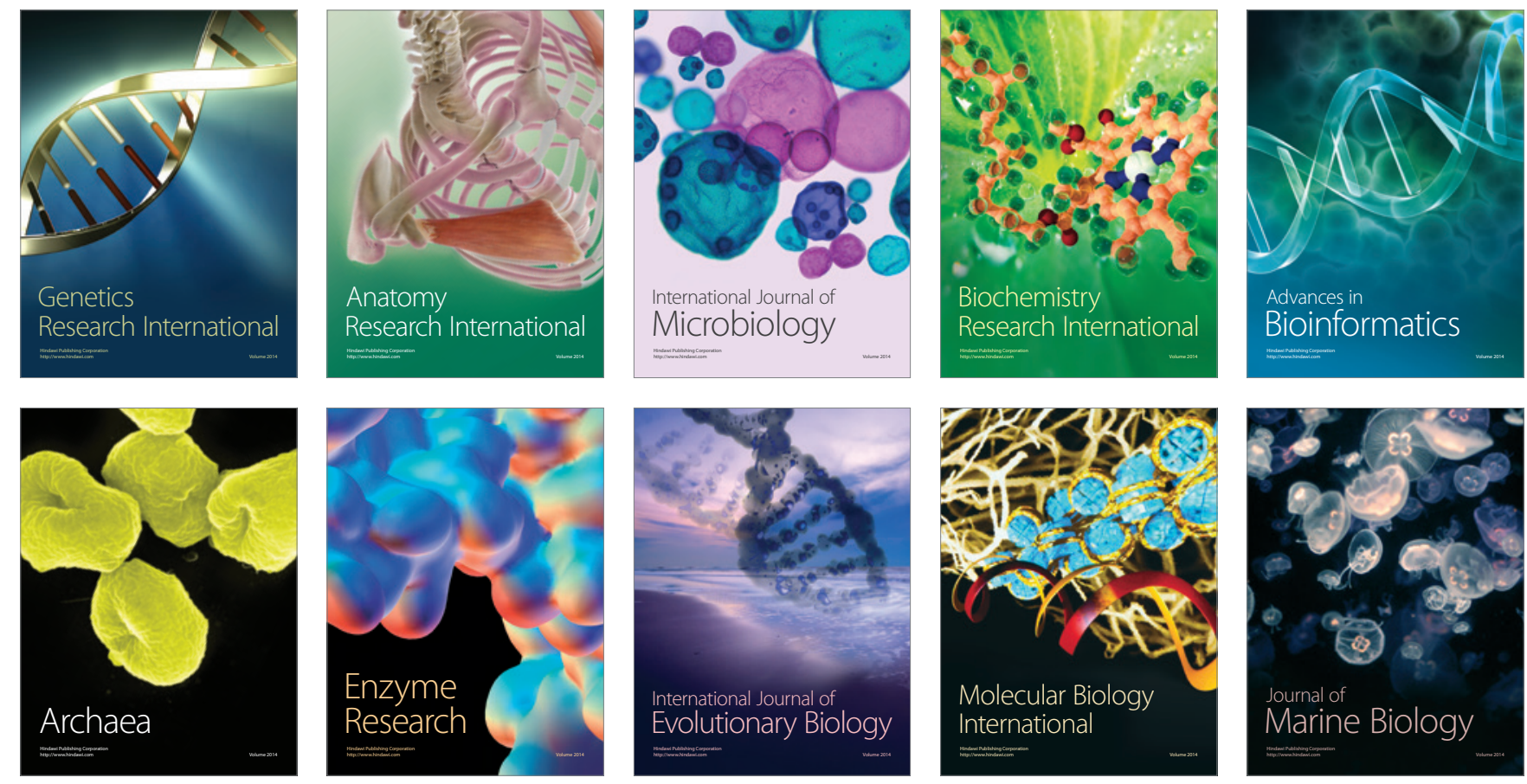